COMPETITOR: Jurnal Pendidikan Kepelatihan Olahraga

Volume 13 Number 1 Year 2021

e-ISSN: 2657-0734 \& p-ISSN: 2085-5389

This work is licensed under a Creative Commons Attribution 4.0 International License

\title{
Saintific Approach With Number Head Together Learning Model Can Improve Sprint Learning Outcomes
}

\author{
Hasniah $^{1^{*}}$, Sudirman Burhanuddin ${ }^{2}$ \\ ${ }^{1,2}$ Physical Education and Sports / Postgraduate Program / Makassar State University / \\ Sulawesi Selatan / Indonesia \\ 1,2J1. Bonto Langkasa, Makassar City, Sulawesi Selatan KP. 90222 \\ ${ }^{1}$ niyahtabara95@gmail.com, ${ }^{2}$ sudirman burhanuddin@yahoo.co.id
}

Received: Oktober 13, 2020; Reviewed: November 18, 2020; Accepted: December 15, 2020;

Published: February 27, 2021

\begin{abstract}
This study is a classroom action research that aims to discover the level of learning outcomes through a scientific approach with the Number Head Together learning model in grade IV. Students at SDN Mangkura I in Makassar City, in the first semester of the academic year 2019/2020, which consisted of 31 students. The study was conducted in two cycles where each cycle consisted of four stages, namely: planning, acting, observing, and reflecting. Cycle I and cycle II were held for 4 meetings. Data collection of learning outcomes was conducted by using observation sheets, worksheets, and the mobility test at the end of the cycle I and cycle II. The collected data were then analyzed quantitatively. Based on those data, the result of the sprint running technique shows that students who completed the learning in the first cycle were 3 people with a percentage of $9.67 \%$, and students who did not complete the learning were 28 people with a percentage of $90.32 \%$. Whereas in cycle II, 27 students completed the learning with a percentage of $87.09 \%$ and 4 students who did not complete the learning with a percentage of $12.91 \%$. The result of the analysis also shows that there is an increase in learning outcomes of sprint running techniques for grade $I V$. Students at SDN Mangkura I in Makassar City. Based on the results of the study it can be concluded that the implementation of a scientific approach with the Number Head Together learning model can improve the learning outcomes.
\end{abstract}

Keywords: Scientific Approach; Number Head Together Learning Model; Learning Outcomes.

\section{INTRODUCTION}

The curriculum must adapt to the nature of education to prepare students to meet the market needs. This curriculum development is needed to emphasize the achievement of educational goals (Musfiqon and Nurdyansyah 2015). The 2013 curriculum focuses on students who have a central position to develop their competence by applying a scientific approach.

Meanwhile, Mangkura I Elementary School in Makassar is a leading school that has implemented the 2013 Curriculum and has become an example for other schools in 
the Makassar area. To achieve the success of learning outcomes it takes the role of a teacher to direct its students. In one process teacher education is a very important component besides other components such as objectives, curriculum, methods, environmental facilities and infrastructure, and evaluation (Daryanto 2013).

Physical education is a medium to achieve internal educational goals by utilizing movement activities that can provide experiences to students in the school environment. As well as it is a medium to encourage physical growth, psychological development, motor skills, knowledge and reasoning, appreciation of values, habituation to a healthy lifestyle which leads to stimulating growth and development, balanced physical and psychological qualities. One type of teaching material in Physical Education subjects that can make them move actively is athletic learning, especially sprinting. This learning can be a forum for training coordination, speed, and leg muscle strength of students. Physical education is a carefully planned sequence of learning experiences designed to meet the development and growth and behavioral needs of each student (Bangun 2016).

Based on the results of observations in grade IV.An at Mangkura I elementary school in Makassar, a total of 31 students consisting of 14 male students and 17 female students. The problem found was during athletic learning, students only focused on how to cover the distance in the shortest possible time without understanding good and proper running techniques and lack on paying attention to the learning material provided by the teacher. This affects the students' self-confidence when doing the sprint running technique that causes students' learning outcomes to be lack. Besides, the KKM score is too high that causes there is no student to achieve the learning outcomes based on standards agreed upon by the school.

In the subject of physical education, teachers are required to be more creative in presenting learning material in a fun way with all the existing conditions and limitations. When a teacher is less creative in choosing a learning model it will affect the absorption of the essence of learning as well as affect the learning outcomes of students in the future. Learning models are systematic procedures or patterns that are used as guidelines for achieving learning objectives in which there are strategies, techniques, methods, materials, media, and learning assessment tools (Afandi et al. 2013).

In addressing these problems, researchers took the initiative to improve learning outcomes by implementing a scientific approach with the Number Head Together (NHT) cooperative learning model. The NHT learning model or shared number thinking is part of a structural cooperative learning model that emphasizes special structures that are 
deliberately designed to influence student interaction patterns. This learning model provides opportunities for students to discuss their opinions or thoughts in small groups and be able to present the results of their group work independently by calling based on the head number. So those students are expected to be more confident and active in terms of affective, cognitive, and psychomotor in solving a problem in the learning process.

\section{METHOD}

The research approach used is quantitative and qualitative approaches which aim to describe the implementation of the scientific approach with the Number Head Together (NHT) learning model which can improve learning outcomes of short distance running techniques in grade IV. An at Mangkura I Elementary school in Makassar. This type of research is Classroom Action Research (CAR) which aims to solve learning problems in class to improve student learning outcomes. To do so, this study applies a scientific approach with the Number Head Together cooperative learning model which is carried out in each cycle, where each cycle consists of two meetings. The cycle will be repeated until the results of the study reach the indicators of success. The indicators of the success of this study are students can achieve learning outcomes based on the minimum completeness criteria value standard $=80$, and the average value of student learning outcomes classical reached $>80 \%$. The application of the positive approach that is applied to the core activities is known as the 5M step, namely: Observing, Asking, Reasoning, Trying, and Communicating. In the Trying and Communicating step, the researcher regulated students' learning activities by applying the Number Head Together cooperative learning model. There are four aspects focused on the observation, namely spiritual attitudes (KI-1), social attitudes (KI-2), knowledge (KI-3), and mobility (KI-4).

Data collection techniques and procedures were carried out employing field observations and documentation. Data collection used research instruments that previously had been validated and tested for the reliability of Cronbach's Alpha in the form of observation sheets, student worksheets, and mobility tests. The observation technique used was a non-participant observation, where the observer was not directly involved in the research subject's activities and only acted as an audience. From the data that had been collected, it was analyzed descriptively with statistical calculations to see the percentage of developments that occur as a whole. 


\section{RESULTS AND DISCUSSION}

The problem found in the initial observation was during athletic learning, namely the sprint running technique. It was found that many students made movements such as hard stomping, hunched body position, short footsteps, and swinging hands with their elbows open at their sides, even though there were still some students who ran while shaking their heads. Students only focused on how they could cover the distance in the shortest possible time without paying attention to proper running techniques. In terms of attitude, students' attention was very lack when the teacher brought the learning material. It was found that many students played and told stories during the learning process, some students lacked discipline because when it was the students' turn to test their motor skills, some students skipped such as going to the canteen or entering the classroom without permission. In addition to these factors, the results of the initial observations of grade IVA in Mangkura I elementary school with such a high KKM score of 80, indicate that no student has achieved the completeness of the learning outcomes according to the standards agreed upon by the school. The value of student learning outcomes in initial observations can be seen in Table 1. This is because students did not understand good and proper running techniques and did not pay attention to the learning material provided by the teacher so that it affected their self-confidence when doing the sprint running techniques which caused results student learning is still lack.

In addressing this problem, the researcher took the initiative to improve the value of student learning outcomes by implementing a scientific approach with the Number Head Together (NHT) cooperative learning model which will be applied in cycle I and cycle II.

Table 1.

Summary of Student Learning Outcomes Value for Each Aspect of Observation Class IVA Mangkura I Elementary School Makassar

\begin{tabular}{|c|c|c|c|c|c|c|}
\hline \multirow[b]{2}{*}{ Field Meeting } & \multicolumn{2}{|c|}{ Affective } & \multirow[b]{2}{*}{ Cognitif } & \multirow[b]{2}{*}{$\begin{array}{l}\text { Psycho- } \\
\text { motor }\end{array}$} & \multirow{2}{*}{$\begin{array}{l}\text { Learning } \\
\text { Outcome }\end{array}$} & \multirow{2}{*}{$\begin{array}{c}\text { Persentage } \\
\text { of Class } \\
\text { Completion }\end{array}$} \\
\hline & Spiritual & Social & & & & \\
\hline Initial Observations & 80,00 & 51,61 & 28,58 & 39,19 & 44,52 & $00,00 \%$ \\
\hline Cycle I ( $1^{\text {st }}$ Meeting) & 80,76 & 62,30 & 52,15 & 40,03 & 54,57 & $03,23 \%$ \\
\hline Cycle I ( $2^{\text {nd }}$ Meeting) & 87,50 & 68,57 & 66,07 & 61,87 & 68,66 & $09,67 \%$ \\
\hline Cycle II ( $1^{\text {st }}$ Meeting) & 90,00 & 79,20 & 81,36 & 73,03 & 79,75 & $45,16 \%$ \\
\hline Cycle II ( $2^{\text {st }}$ Meeting) & 96,66 & 80,66 & 90,53 & 82,32 & 87,17 & $87,09 \%$ \\
\hline
\end{tabular}




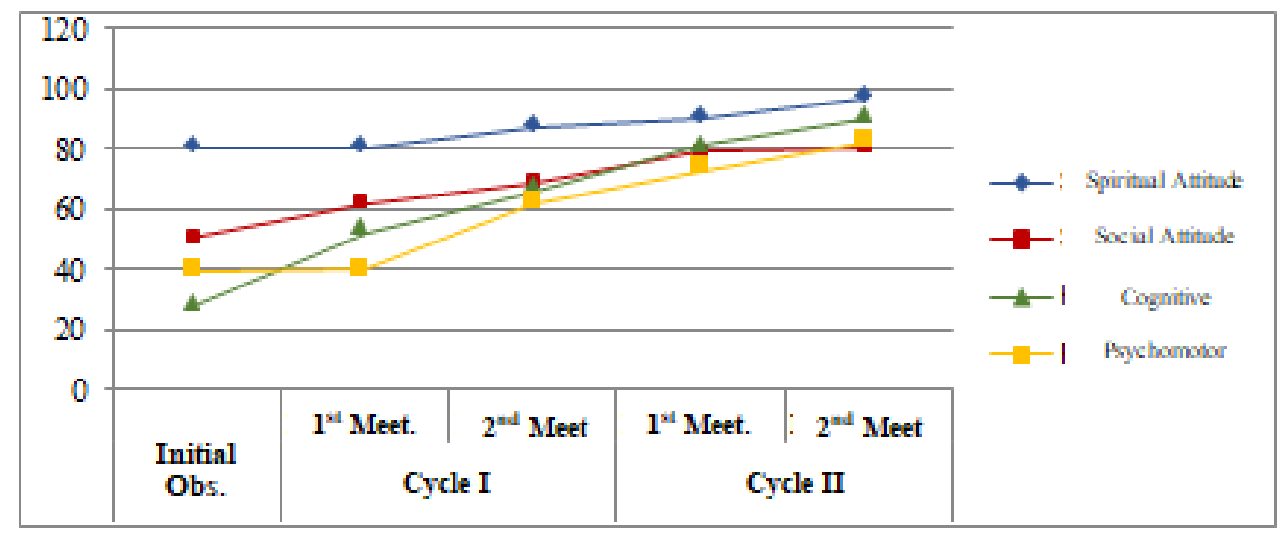

Ficture 1.

Graph of Learning Outcomes Value for Each Aspect of Observation

During the first cycle, a scientific approach was applied with the cooperative learning model type Number Head Together as many as two meetings. The division into one group consisting of five students was carried out heterogeneously based on the value of student learning outcomes obtained during initial observations. In the first cycle, the value of the learning outcomes obtained was 68.66 in the poor category with 3 students (9.67\%) who completed learning and 28 students (90.33\%) who did not complete their studies. During the first cycle, it can be seen that there is an improvement in the completeness of the learning outcome values can be seen in table 2 and graph 2 , but this improvement is still not satisfactory so it is necessary to continue to the next stage of the cycle. "Each student has different traits, and receives influence and treatment from his family, which is also different. Thus it is natural that each student has his characteristics" (Ibrahim and Syaodih 1996). "Upon the opinion about the factors that affect the learning process and outcomes students have certain characteristics, both physiological and psychological. Regarding physiology, it is how the physical condition, the five senses, and so on. Meanwhile, the psychological ones are interests, level of intelligence, talents, motivation, cognitive abilities, and so on. All of these can affect how the process and learning outcomes are" (Purwanto 2017).

Based on the opinion above there are differences in the characteristics of these students, causing differences in student motivation among fellow group members. When group discussions were usually seen as being dominated by two or three students who were actively learning, it resulted from other student members becoming passive and causing disinterest in the learning material provided. When this happened, students' attention would be distracted and less discipline and interfered with the ongoing learning 
process. Another obstacle experienced during the first cycle was the class could not be able to display images in the form of learning videos due to technical problems. Factors that can hinder students' learning motivation must be addressed immediately so that the researcher was trying to show several videos about sprint running techniques and carrying out heterogeneous group reshuffles in which one group consists of three students that would be applied in cycle II.

Table 2.

Summary of Comparison of the Completeness of Learning Outcomes in Cycle I and Cycle II in Class IVA Students at Mangkura I Elementary School in Makassar

\begin{tabular}{cccccccc}
\hline No. & Value Range & Criteria & Explaination & \multicolumn{2}{c}{ Cycle I } & \multicolumn{2}{c}{ Cycle II } \\
\hline 1 & $93-100$ & Very Good & Completed & 0 & $0 \%$ & 4 & $12,90 \%$ \\
2 & $86-93$ & Good & Completed & 1 & $3,23 \%$ & 14 & $45,17 \%$ \\
3 & $80-86$ & Fair & Completed & 2 & $6,45 \%$ & 9 & $29,03 \%$ \\
4 & $<80$ & Poor & Uncompleted & 28 & $90,32 \%$ & 4 & $12,90 \%$ \\
\hline & Total & & $\mathbf{3 1}$ & $\mathbf{1 0 0 \%}$ & $\mathbf{3 1}$ & $\mathbf{1 0 0 \%}$ \\
\hline
\end{tabular}

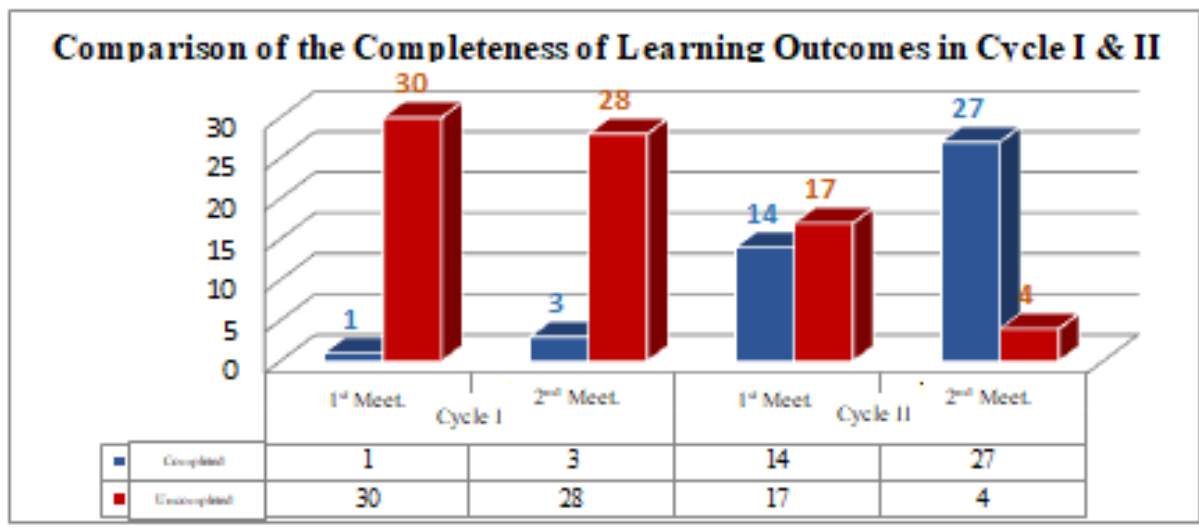

Ficture 2.

Graph of Comparison of the Completeness of Learning Outcomes in Cycle I and Cycle II

During the second cycle, a scientific approach was applied with the cooperative learning model Number Head Together as many as two meetings. 87.17 was in the good category with 27 students (87.09\%) who completed their studies and 4 students $(12.91 \%)$ who did not complete their studies. Therefore, this study has achieved the classical completion criteria, namely $>80 \%$, so this stage is said to be successful and does not need to be continued to the next stage of the cycle. 
"Motivation to learn can be conceptualized as a general trait or a situation-specific state (Brophy 1987). As a general trait, it is characterized by a desire to learn no matter what the subject matter or topic. People just want to do well at a particular task or in a particular subject field." (James and Jhon 2013).

Based on this theory, during the learning process, there was a significant change in student behavior, that is most students seemed to be active in learning and active in group discussions. Students will be motivated to do a task if the assignment given will be challenging but not too difficult. Besides, getting good support from fellow members of the right group can minimize students' worries in expressing their opinions without being dominated by other members. By using the heterogeneous group reshuffling students will learn to accept different opinions, can stimulate student motivation to learn psychologically, provide better learning opportunities, support each other, and direct to gain knowledge or master the material provided. "Motivation also has a role or function and relationship in learning because motivation will determine the identity of the student's learning efforts" (Husamah et al. 2016).

Based on research during the cycle I and cycle II, it shows that the cooperative learning model type Number Head Together can overcome learning problems caused by differences in student characteristics in a class thus it can increase students' selfconfidence and learning motivation which will affect the value of student learning outcomes.

\section{CONCLUSIONS AND SUGGESTIONS}

Based on the results of research that have been carried out at Mangkura I elementary school in Makassar through the implementation of a scientific approach with the cooperative learning model Number Head Together, it can increase the value of learning outcomes in the sprint running technique of class IV. Students on athletic learning. Through the scientific approach, students become the main focus in the learning process where students try to find out and solve a problem according to the $5 \mathrm{M}$ scientific steps, namely: Observing, Asking, Reasoning, Trying, and Communicating in the context of the learning process. Regulating student learning activities by applying the Number Head Together cooperative learning model can embrace every difference in student characteristics in the class to increase their self-confidence and learning motivation which will affect the value of student learning outcomes. 


\section{REFERENCES}

Afandi, MSP, Evi Chamalah, SP Oktarina Puspita Wardani, H. Gunarto, and M. Hum. (2013). Model dan Metode Pembelajaran di Sekolah. UNISSULA PRESS.

Bangun, Sabaruddin Yunis. (2016). Peran Pendidikan Jasmani Dan Olahraga Pada Lembaga Pendidikan Di Indonesia. Publikasi Pendidikan 6(3).

Daryanto. (2018). Penelitian Tindakan Kelas Dan Penelitian Tindakan Sekolah. Yogyakarta: Penerbit Gava Media.

Hafifudin, Abdul. (2014). Permendikbud No. 66 Tahun 2013 Tentang Standar Penilaian Pendidikan. (https://www.slideshare.net/mobile/AbdulHafifudin/permendikbud-no-66-th2013-ttg-std-penilaian).

Hakim, Lukmanul. (2013). Sistem Penilaian Dalam Kurikulum 2013. Www.Academia.Edu. Retrieved (https://www.academia.edu/5253890/Sistem Penilaian dalam Kurikulum 2013 Kajian Dokumen).

Husamah, Yuni Pantiwati, Arina Restian, and Puji Sumarsono. (2016). Belajar dan Pembelajaran. Malang: UMM Pres.

Ibrahim, R. and Nana Syaodih. (1996). Perencanaan Pengajaran. Jakarta: Penerbit Rineka Cipta.

James, Keefe and Jenkins Jhon. (2013). Instruction and the Learning Environment. USA: Routledge.

Musfiqon, Muhammad and Nurdyansyah. (2015). Pendekatan Pembelajaran Saintifik. Sidoarjo: Nizamia Learning Center.

Purwanto, Ngalim. (2017). Psikologi Pendidikan. Bandung: PT Remaja Rosdakarya. 